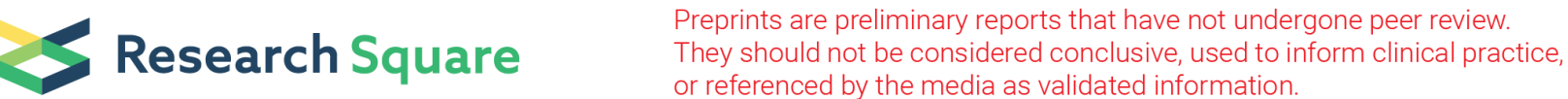

\section{Formation Mechanism of "Encapsulated" Carbide Slag Composite Alkalinity Sustained-release Particles for the Source Control of Acid Mine Drainage}

Jichi Bai

Liaoning Technical University

Haiqin Zhang ( $\sim$ zhanghaiqin@Intu.edu.cn )

Liaoning Technical University

Liping Xiao

Qingdao University of Technology

\section{Research Article}

Keywords: AMD, Alkaline activation, Interfacial reactions, C-S-H,Bentonite

Posted Date: August 4th, 2021

DOI: https://doi.org/10.21203/rs.3.rs-764148/v1

License: (c) (1) This work is licensed under a Creative Commons Attribution 4.0 International License.

Read Full License

Version of Record: A version of this preprint was published at Scientific Reports on December 1st, 2021. See the published version at https://doi.org/10.1038/s41598-021-03277-w. 


\section{Abstract}

Acid mine drainage (AMD) has caused serious and long-lasting damage to the environment in many countries. The source control of AMD is considered to be the most direct and effective method of remediation. Carbide slag is an industrial waste which is considered as a potential treatment material for AMD treatment due to the strong alkalinity. However, the application of carbide slag in the source control of AMD encounters difficulties due to its fast alkalinity release rate. This is a first attempt to mix carbide slag with bentonite to prepare alkalinity sustained-release particles for the source control of AMD. Results showed that the gel phase $(\mathrm{C}-\mathrm{S}-\mathrm{H})$ formed between the interface of carbide slag and bentonite encapsulated the surface of the $\mathrm{Ca}(\mathrm{OH})_{2}$ which grain decreases from $267 \mathrm{~nm}$ to $211 \mathrm{~nm}$. The optimum preparation conditions are suggested as follows: a mass ratio of bentonite to carbide slag of 3:7, a $\mathrm{Na}_{2} \mathrm{CO}_{3}$ dose of $10 \mathrm{wt} \%$, and a calcination temperature of $500^{\circ} \mathrm{C}$ for $1 \mathrm{~h}$. The particles can remove 105 $\mathrm{mg} / \mathrm{g} \mathrm{Cu}^{2+}$ within $12 \mathrm{~h}$, and the loss rate is only $7.8 \%$. Compared with carbide slag, the alkalinity release time of the particles is prolonged by 4 times.

\section{Introduction}

Mineral resources are a perpetual driving force of social development, but the environmental problems caused by mining have become increasingly prominent and persist for a long time, even after mine closure. Pollutants in mining areas diffuse to the atmosphere ${ }^{[]}$, soil ${ }^{[]}$and rivers ${ }^{\square}$. Acid mine drainage (AMD) is characterized by its concealment, strong acidity, high concentrations of heavy metals, and persistence ${ }^{[]}$. The Picher mining area in the United States ${ }^{\square}$ and the Carnot mine in France ${ }^{\square}$ are typical cases of serious AMD pollution. AMD has caused serious damage to approximately 72000 hectares of lakes and reservoirs worldwide and has become a serious environmental problem worldwide ${ }^{\square}$.

The traditional AMD terminal treatment method is generally laborious and time-consuming. Compared with terminal treatment, source control can minimize the formation and diffusion of AMD. The formation of $A M D$ is due to the combined action of microorganisms and oxygen, as well as sulfide oxidation during the cyclic transformation of $\mathrm{Fe}^{2+}$ and $\mathrm{Fe}^{3+}$. If one or two formation conditions are blocked, the risk of AMD formation will be effectively reduced, such as live bacteria inhibition ${ }^{\natural}$, alkaline material filling ${ }^{[]}$, anaerobic limestone reaction ditching ${ }^{[}$, waste packaging ${ }^{[]}$and wetland construction ${ }^{[]}$. Anoxic limestone drains (ALDs) were first proposed by Turner and McCoy at 1990[]. However, ALDs with limestone can only increase the $\mathrm{pH}$ to 8 and cannot completely remove metal ions such as $\mathrm{Fe}^{2+}$ and $\mathrm{Mn}^{2+\square}$. Moreover, $\mathrm{FeCO}_{3}$ and $\mathrm{MnCO}_{3}$ colloids are easily generated, leading to incongruent dissolution, which shortens the service life of the structure ${ }^{\natural}$. Therefore, to overcome the above shortcomings, the development of alternative limestone materials has become the goal of many studies.

Blast furnace slag ${ }^{\square}$, fly ash ${ }^{\square}$ and serpentinite ${ }^{[]}$have all been considered as a replacement to limestone. Petrik ${ }^{\square}$ suggested that fly ash alone is a cost-effective alkaline treatment material, but fly ash increases the effluent turbidity and is not conducive to the separation of metals and raw materials. Turigan ${ }^{\square}$ 
replaced limestone with low-grade nickel soil, but the nickel soil could buffer the $\mathrm{pH}$ to only 4.7 at the highest, allowing very few types of heavy metals to be removed. The main component of carbide slag (CS) is $\mathrm{Ca}(\mathrm{OH})_{2}$, which has high solubility, large alkalinity release and high removal efficiency for heavy metal ions ${ }^{\square}$. Based on the above characteristics, carbide slag has been used for the fixation of heavy metals in soil and the removal of phosphorus in sewage in recent years ${ }^{[1]}$. However, there are few studies on the treatment of AMD with carbide slag instead of limestone. Due to the fast alkalinity release rate of carbide slag, the service life may be shortened. Therefore, it is necessary to modify and reduce the alkalinity release rate. In the presence of silicoaluminate, $\mathrm{Ca}(\mathrm{OH})_{2}$ reacts with volcanic ash to produce hydration products such as C-S-H, C-A-H and C-A-S-H, which improves the mechanical strength of carbide slag $^{\square}$. Sun ${ }^{[31]}$ found that the formation of hydration products could slow down the alkalinity release rate of $\mathrm{Ca}(\mathrm{OH})_{2}$, but an excessive gel content led to a decrease in permeability after hardening ${ }^{\square}$. Therefore, a clay mineral with high permeability, Bentonite, may be the best choice to improve the above-mentioned defects.

In this study, carbide slag was used as the main material, bentonite was used as the Si/Al source, and $\mathrm{Na}_{2} \mathrm{CO}_{3}$ was used as the activator to granulate the two kinds of powder materials. The hydrated products

were used to enhance the mechanical strength of the particles and improve the fast alkalinity release and large sludge volume defects of carbide slag, thereby preparing a new filling material for ALDs and realizing the resource utilization of carbide slag. The effects of the ratio of bentonite to carbide slag, $\mathrm{Na}_{2} \mathrm{CO}_{3}$ dose and calcination temperature on the particle loss rate and $\mathrm{Cu}^{2+}$ removal rate were analysed by single-factor experiments. The effects of various factors on the particle composition and microstructure were characterized by $\mathrm{X}$-ray diffraction (XRD) and scanning electron microscopy (SEM). The optimum preparation conditions for carbide slag composite alkalinity sustained-release particles were determined, and the basicity release rates of the particles and carbide slag were compared.

\section{Materials And Methods}

\subsection{Materials and chemicals}

The carbide slag used in this study was provided by Fuxin Acetylene Factory, Liaoning Province, China, and the bentonite was sodium bentonite, which was provided by Wanpeng Mine, Liaoning Province, China. The X-ray fluorescence (XRF) results for determining the composition of the two materials are shown in Table 1. Before the experiment, the two raw materials were ground, passed through a 200-mesh screen, and dried in an oven at $105^{\circ} \mathrm{C}$ for $2 \mathrm{~h}$. 
Table 1

Chemical compositions of the carbide slag and bentonite used in \%wt oxide.

\begin{tabular}{|lllllllll|}
\hline Oxide & $\mathrm{CaO}$ & $\mathrm{SiO}_{2}$ & $\mathrm{Al}_{2} \mathrm{O}_{3}$ & $\mathrm{Na}_{2} \mathrm{O}$ & $\mathrm{Fe}_{2} \mathrm{O}_{3}$ & $\mathrm{MgO}$ & $\mathrm{TiO}_{2}$ & $\mathrm{~K}_{2} \mathrm{O}$ \\
\hline carbide slag & 93.65 & 2.97 & 0.82 & 0.71 & 0.22 & 0.15 & 0.06 & - \\
\hline bentonite & 2.24 & 73.33 & 13.55 & 4.25 & 2.26 & 3.59 & 0.12 & 0.50 \\
\hline
\end{tabular}

A small amount of $\mathrm{Na}, \mathrm{Al}$ and other metal ions were detected in the chemical composition of carbide slag (Table 1), which may have been derived from the acetylene raw material (calcium carbide) or mixed impurities in the production process. According to the chemical composition of bentonite, a large amount of $\mathrm{Na}^{+}$replaces $\mathrm{Ca}^{2+}$, belonging to Na-bentonite (Na-Bent), and contains small amounts of iron, magnesium, potassium and titanium (Table 1), which may be caused by the substitution of the aluminium oxide octahedral structures in montmorillonite by other divalent cations ${ }^{\square}$. The XRD results showed that the main mineral components of bentonite were montmorillonite and quartz, and the main component of carbide slag was $\mathrm{Ca}(\mathrm{OH})_{2}$.

A copper ion solution was prepared with CuSO4. $\mathrm{HNO}_{3}$ and $\mathrm{NaOH}$ were used to adjust the $\mathrm{pH}$ of the solution. $\mathrm{Na}_{2} \mathrm{CO}_{3}$ was used as an activator for the preparation of the particles. The above chemical reagents were analytically pure.

\subsection{Preparation of the granular composites}

The preparation of composite particles mainly includes raw material mixing, particle forming and hightemperature roasting. First, bentonite and carbide slag were mixed according to mass ratios of 1:9 9:1. Additionally, to study the effect of $\mathrm{Na}_{2} \mathrm{CO}_{3}$ on the particles, $0 \sim 10 \% \mathrm{Na}_{2} \mathrm{CO}_{3}$ was added to the raw materials. To ensure that the raw materials met the plastic requirements of machine processing, distilled water was added to the raw materials, the moisture content was controlled at $60 \%$, and the raw materials and water were mixed by hand for $15 \mathrm{~min}$ to ensure the full dispersion and dissolution of the mixture. Then, the mixture was machine processed into small cylindrical particles with a diameter of $2 \mathrm{~mm}$ and a length of $3 \mathrm{~mm}$. Finally, the formed particles were calcined at $200 \sim 800^{\circ} \mathrm{C}$ and then cooled to room temperature. In order to compare the influence of calcination temperature on the particles, uncalcined particles were prepared at room temperature and stored in sealable plastic bags.

\subsection{Copper removal experiment}

A series of particles were prepared according to different mass ratios of bentonite to carbide slag, doses of $\mathrm{Na}_{2} \mathrm{CO}_{3}$, and calcination temperatures. By comparing the removal rates of copper ions by particles prepared under different conditions, the treatment effect of particles on copper-containing wastewater was analysed. The $\mathrm{pH}$ was adjusted to $3.2( \pm 0.05)$ with $10 \% \mathrm{HNO}_{3}$ and $10 \% \mathrm{NaOH}$. Briefly, $0.20 \mathrm{~g}$ of composite particles were placed into a $250 \mathrm{ml}$ beaker, and $100 \mathrm{ml}$ of simulated wastewater at a concentration of $300 \mathrm{mg} / \mathrm{L}$ was added. The solution was treated for $12 \mathrm{~h}$ under static conditions. The 
residual $\mathrm{Cu}^{2+}$ concentration in the solution was determined by flame atomic spectrophotometer (Japan, HITACHI Z-2000) at $324.8 \mathrm{~nm}$ wavelength.

\subsection{Characterization of granular composites}

To characterize the mechanical strength of the particles, the percentage of mass loss of the particles in water to the original mass was measured, namely, the loss rate. The specific operation involved taking the same mass of particles in a $250 \mathrm{~mL}$ conical flask, adding $100 \mathrm{~mL}$ of distilled water, and placing the flask in a shaker at $100 \mathrm{rpm}$ for $12 \mathrm{~h}$. Then, the particles were dried at $105^{\circ} \mathrm{C}$ for $2 \mathrm{~h}$, cooled at room temperature and passed through a $0.5 \mathrm{~mm}$ mesh sieve. The remaining particles were weighed, and the loss rate was calculated. The larger the loss rate is, the worse the mechanical strength of the particles.

The morphology and structure of the different particles were characterized by SEM (German Nova 400 Nano). The accelerating voltage was $10 \mathrm{kV}$. Due to the low conductivity of the composite particles, the surface of the particles needed to be sprayed with gold for 3 min before testing.

The mineral composition of the particles was characterized by XRD (Rigaku Ultima IV, Japan). The particles were manually ground into powder and tested by X-ray bombardment with a Cu-Ka radiation source. The specific parameter settings were as follows: the incident wavelength was $\lambda=1.5418 \AA$, the power supply voltage was $40 \mathrm{kV}$, the current was $40 \mathrm{~mA}$, the scanning angle was $5 \sim 90^{\circ}$, and the angular velocity was $4^{\circ} / \mathrm{min}$.

\section{Results And Discussion}

\subsection{Effect of the mass ratio of bentonite to carbide slag on the particles}

Bentonite and carbide slag were mixed at mass ratios of 9:1 1:9, and $5 \mathrm{wt} \% \mathrm{Na}_{2} \mathrm{CO}_{3}$ was added. Then, the slag was roasted at $500^{\circ} \mathrm{C}$ for $1 \mathrm{~h}$ to obtain a series of particles. The removal rate of $\mathrm{Cu}^{2+}$ and loss rate of particles prepared with different mass ratios of bentonite and calcium carbide are shown in Fig. 1. Increasing the proportion of carbide slag was conducive to the formation of $\mathrm{Cu}^{2+}$ precipitates. When the ratio of bentonite to carbide slag decreased from 9:1 to 5:5, the particle loss rate decreased from 40.36$8.98 \%$. However, when the ratio decreased to $1: 9$, the particle loss rate increased to $40.1 \%$. This indicated that the loss rate could be controlled by changing the ratio.

The loss of three typical particles in water are shown in Fig. 2 (a)-(c). As the contact time with water increased, the 9:1 particles gradually ruptured into small blocks, while the 1:9 particles gradually became spherical. This morphological change indicates that when the ratio of bentonite to carbide slag is greater than $5: 5$, the internal force is caused by bentonite swelling due to water absorption ${ }^{\square}$. When the ratio is less than 5:5, external forces such as flow shear and friction are concentrated at the corner of the particle, leading to the separation of powder from the particle surface. This separation is the main reason for the increase in loss rate, indicating that the internal cohesion of the particle is insufficient. When the ratio of 
bentonite to carbide slag is $5: 5$, the particle morphology is complete, indicating that the cohesive force inside the particle can overcome the expansion of bentonite, water shear and friction to achieve balance; thus, the loss rate reaches a minimum.

The surface morphologies of the three typical particles are compared in Fig. 2 (d)-(f). As shown in Fig. 2d, the 9:1 particle surface exhibits a smooth, crack-free compact structure. Figure 2e corresponds to the 5:5 particles and obvious small cracks are observed on their surface. These cracks provide buffer space for bentonite to absorb water and expand, thereby reducing the particle loss rate. The surface morphology of the 1:9 particles is shown in Fig. $2 \mathrm{f}$. The surface became rough, and the number of cracks decreased. This structure shows that the particles exposed to the surface more easily fall off in water under the action of shear and friction, as shown by the macro-morphology in Fig. 2c.

The changes in the interlayer spacing of montmorillonite in unburned bentonite, calcined bentonite $\left(500^{\circ} \mathrm{C}\right)$ and 9:1 particles are shown in Fig. 3a. No characteristic peaks representing the interlayer spacing were found in the 5:5 and 1:9 particles, indicating that the layered structure disappeared. The $d_{001}$ value of unburned bentonite was $1.06 \mathrm{~nm}$, which is the characteristic peak of sodium montmorillonite. After calcination at $500^{\circ} \mathrm{C}$, the $\mathrm{d}_{001}$ value decreased to $0.96 \mathrm{~nm}$. This result was consistent with the interlayer spacing of montmorillonite without interlayer-bound water. However, when a small amount of carbide slag was added, there were two weak characteristic peaks within $2 \theta=6-10^{\circ}$. The $d_{001}$ value of the characteristic peak of the layered structure increased to $1.28 \mathrm{~nm}$. This result is consistent with the $d_{001}$ value of Ca-montmorillonite containing a layer of crystal water ${ }^{\square}$, indicating that $\mathrm{Ca}^{2+}$ in carbide slag enters the interlayer of montmorillonite, resulting in the transformation of some Na-bentonite to $\mathrm{Ca}$ bentonite. The $\mathrm{d}_{001}$ value of another characteristic peak was consistent with that of montmorillonite, which had its lost interlayer-bound water. This part of the bentonite is the main cause of the water swelling and cracking of particles.

Figure $3 b$ compares the phase change of particles at different ratios. The 9:1 particles showed an obvious increase between $18^{\circ}$ and $25^{\circ}$, indicating that new crystalline phases were formed, but their crystallinity was too low. The characteristic $\mathrm{SiO}_{2}$ peaks at $35.89^{\circ}$ and $31.28^{\circ}$ widened, and a flat and wide peak was observed at $27.79^{\circ}$. Phase analysis showed that $\mathrm{SiO}_{2}$ was transformed into $\mathrm{NaAl}_{2}\left(\mathrm{AlSiO}_{3}\right)_{10}(\mathrm{OH})_{2}$ (PDF 24-1047), indicating that the crystallinity of $\mathrm{SiO} 2$ decreased and participated in the formation of silicate. As the ratio was decreased to $5: 5$, the characteristic peaks of $\mathrm{SiO}_{2}$ at $28.43^{\circ}$ and $31.28^{\circ}$ disappeared, but no peaks appeared, indicating that $\mathrm{SiO}_{2}$ existed in an amorphous form. When the ratio was further decreased to $1: 9$, the characteristic peak of montmorillonite at $19.88^{\circ}$ disappeared, indicating that montmorillonite transformed into an amorphous state.

The above results indicate that the formation of an amorphous gel is conducive to enhancing the mechanical strength of particles, and $\mathrm{SiO}_{2}$ in bentonite is preferentially converted to an amorphous state over montmorillonite. Therefore, when the proportion of bentonite is greater than 1 , the layered structure of montmorillonite is retained, and the particles are more likely to be destroyed due to water absorption 
and expansion. When the proportion of bentonite is less than 1, the insufficient production of gel leads to an increase in the loss rate.

\subsection{Effect of $\mathrm{Na}_{2} \mathrm{CO}_{3}$ dose on the particles}

It can be seen from Sect. 3.1 that increasing the proportion of carbide slag can effectively improve the removal rate of $\mathrm{Cu}^{2+}$ ions, and the formation of amorphous gel is conducive to enhancing the particle strength. According to Provis at al ${ }^{[}$, since the formation of $\mathrm{CSH}, \mathrm{CAH}$, and $\mathrm{CASH}$ gels depends on the activation of alkali metal hydroxides or carbonates (i.e., $\mathrm{Na}_{2} \mathrm{CO}_{3}$ ). We expect to increase the proportion of calcium carbide slag as much as possible while maintaining a low loss rate. Therefor a series of particles were obtained by increasing the dose of $\mathrm{Na}_{2} \mathrm{CO}_{3}$ from $0-10 \%$ at different ratios $(5: 5,4: 6,3: 7)$ and roasting at $500^{\circ} \mathrm{C}$ for $1 \mathrm{~h}$.

Figure 4 shows the loss rate and $\mathrm{Cu}^{2+}$ removal rate of the different particles. The $\mathrm{Na}_{2} \mathrm{CO}_{3}$ content increased from $0-10 \%$, and the loss rates of the three groups of particles exhibited different degrees of decrease. The 7:3 series of particles decreased the most, from $63.56-7.40 \%$. When $10 \% \mathrm{Na}_{2} \mathrm{CO}_{3} \mathrm{was}$ added, the loss rate of the $3: 7$ particles was $7.40 \%$, which was similar to the loss rate (5.82\%) of the $5: 5$ particles (Fig. 4a). These loss rate results indicate that increasing the amount of $\mathrm{Na}_{2} \mathrm{CO}_{3} \mathrm{can}_{\text {reduce the }}$ loss rate.

The removal rate of $\mathrm{Cu}^{2+}$ decreased when increasing the $\mathrm{Na}_{2} \mathrm{CO}_{3}$ dose from $0-10 \%$ (Fig. 4b), indicating that the addition of $\mathrm{Na}_{2} \mathrm{CO}_{3}$ had a negative effect on the removal of $\mathrm{Cu}^{2+}$. However, the copper ion removal rate of the 7:3 particles was better than that of the other particles. The loss rate of the 7:3 particles with $10 \% \mathrm{Na}_{2} \mathrm{CO}_{3}$ was less than $10 \%$.

The surface morphologies of the $7: 3$ particles with $0 \%$ and $10 \% \mathrm{Na}_{2} \mathrm{CO}_{3}$ are shown in Fig. 5. The surfaces of the particles without $\mathrm{Na}_{2} \mathrm{CO}_{3}$ mainly consisted of large irregular particles stacked together in a loose structure, and the edges were rough (Fig. 5a). This structure led to a high loss rate of particles. The XRD analysis of the particles without $\mathrm{Na}_{2} \mathrm{CO}_{3}$ (Fig. 6) shows that the composition of the particles included montmorillonite and $\mathrm{SiO}_{2}$ from the bentonite and $\mathrm{Ca}(\mathrm{OH})_{2}$ and $\mathrm{CaCO}_{3}$ from the carbide slag. This indicated that the main composition remain unchanged A slight bulge in the substrate was observed between $25^{\circ}$ and $40^{\circ}$ because $\mathrm{Ca}(\mathrm{OH})_{2}$ can generate amorphous $\mathrm{CSH}$ through the pozzolanic reaction[]; however, the amount of amorphous $\mathrm{CSH}$ was not enough to reduce the loss rate.

When increasing the $\mathrm{Na}_{2} \mathrm{CO}_{3}$ content to $10 \%$, the particle surface flattened, and cracks with clear edges appeared, indicating that the particles lost water and shrunk; thus, the structure became compact (Fig. 5b). Based on Fig. 6, for the particles with $10 \% \mathrm{Na}_{2} \mathrm{CO}_{3}$, the characteristic peaks at $19.79^{\circ}$ and $21.73^{\circ}$ disappeared, and the background hump between $25^{\circ}$ and $40^{\circ}$ became more obvious than that for the particles without $\mathrm{Na}_{2} \mathrm{CO}_{3}$. This result indicates that $\mathrm{Na}_{2} \mathrm{CO}_{3}$ plays a promoting role in the transformation of montmorillonite and $\mathrm{SiO}_{2}$ to an amorphous state because $\mathrm{Na}_{2} \mathrm{CO}_{3}$ can enhance the 
reactivity of $\mathrm{Al}$ and $\mathrm{Si}$ in clay and promote the formation of gels $\mathrm{s}^{\square}$. Therefore, with an increasing $\mathrm{Na}_{2} \mathrm{CO}_{3}$ dose, the transformation of $\mathrm{SiO}_{2}$ and montmorillonite to an amorphous state was promoted, the gel content in the particles increased, and the particle loss rate was effectively reduced.

\subsection{Effect of the roasting temperature}

When the mass ratio of bentonite to carbide slag was $3: 7$ and the dose of $\mathrm{Na}_{2} \mathrm{CO}_{3}$ was $10 \%$ of the total mass, a series of particles were obtained after treatment for $1 \mathrm{~h}$ at different calcination temperatures to study the effect of calcination temperature on the particles. Regarding the particles prepared at room temperature, the loss rate reached $44.07 \%$, and the removal rate of $\mathrm{Cu}^{2+}$ reached $100 \%$. Regarding the particles calcined at $200^{\circ} \mathrm{C}$, the loss rate greatly decreased to $18.73 \%$, and the $\mathrm{Cu}^{2+}$ removal rate decreased to $83.46 \%$ (Fig. 7). This decrease indicates that the mechanical strength of uncalcined particles is poor, and an excessive loss rate leads to the removal of $\mathrm{Cu}^{2+}$, which is consistent with the research results of Zhan ${ }^{\square}$. However, an excessive loss rate leads to an increase in effluent turbidity and sludge. When increasing the temperature from $200^{\circ} \mathrm{C}$ to $500^{\circ} \mathrm{C}$, the loss rate of particles decreased from $18.73-8.69 \%$. However, when the calcination temperature was increased to $800^{\circ} \mathrm{C}$, the loss rate increased to $19.14 \%$. The removal rate of $\mathrm{Cu}^{2+}$ decreased with an increasing preparation temperature. According to Fig. 7, the loss rate of particles calcined at $500^{\circ} \mathrm{C}$ was the smallest, and the removal ratio of $\mathrm{Cu}^{2+}$ was $73.65 \%$. Therefore, $500^{\circ} \mathrm{C}$ was set as the preparation temperature of the particles.

The XRD patterns of the particles prepared at different temperatures are compared in Fig. 8 . In the uncalcined particles, $\mathrm{Na}_{2} \mathrm{Ca}\left(\mathrm{CO}_{3}\right)_{2} \cdot 5 \mathrm{H}_{2} \mathrm{O}$ was detected based on the characteristic peaks at $2 \theta=13.84^{\circ}$, $37.83^{\circ}$ and $32.86^{\circ}$, while the characteristic peaks of $\mathrm{Na}_{2} \mathrm{CO}_{3}$ disappeared. This result indicates that a hydration reaction between $\mathrm{Na}_{2} \mathrm{CO}_{3}$ and carbide slag occurs, providing a precursor for the combination of bentonite and carbide slag after calcination. The characteristic peak of $\mathrm{SiO}_{2}$ from the bentonite disappeared, while the montmorillonite structure was retained. This is because montmorillonite with $\mathrm{Al}$ and $\mathrm{Si}$ in its crystal structure cannot participate in the volcanic ash reaction $\square$. Therefore, $\mathrm{SiO}_{2}$ preferentially transforms to an amorphous state over montmorillonite, forming CSH and other hydrates. The formation of hydration products gives the particles a certain mechanical strength, but insufficient production leads to a high particle loss rate. As the calcination temperature was increased to $500^{\circ} \mathrm{C}$, the characteristic peaks of montmorillonite at $7.12^{\circ}$ and $19.72^{\circ}$ disappeared, indicating that the layered structure collapsed, and that the montmorillonite structure was destroyed. This is because the increase in the content of amorphous silicate transferred from $\mathrm{Si}$ and $\mathrm{Al}$ in the montmorillonite crystal structure with the increase of temperature further decreased the loss rate. This is consistent with the research results of Okanoप.

The reaction of $\mathrm{Ca}(\mathrm{OH})_{2}$ with silicoaluminate can be summarized as ${ }^{[38]}$ :

$6 \mathrm{CH}(\mathrm{s})+\mathrm{AS}_{2}(\mathrm{~s})+9 \mathrm{H}(\mathrm{l}) \rightarrow \mathrm{C}_{4} \mathrm{AH}_{13}(\mathrm{~s})+2 \mathrm{CSH}(\mathrm{s})$

$5 \mathrm{CH}(\mathrm{s})+\mathrm{AS}_{2}(\mathrm{~s})+3 \mathrm{H}(\mathrm{I}) \rightarrow \mathrm{C}_{3} \mathrm{AH}_{6}(\mathrm{~s})+2 \mathrm{CSH}(\mathrm{s})$ 
$3 \mathrm{CH}(\mathrm{s})+\mathrm{AS}_{2}(\mathrm{~s})+6 \mathrm{H}(\mathrm{I}) \rightarrow \mathrm{C}_{2} \mathrm{ASH}_{8}(\mathrm{~s})+\mathrm{CSH}(\mathrm{s})$

When the temperature was increased from $500^{\circ} \mathrm{C}$ to $600^{\circ} \mathrm{C}$, the background hump became obvious between $30^{\circ}$ and $40^{\circ}$, indicating that new crystalline phases were formed and the crystallinity increased,

which was caused by the transformation of the gel to a crystalline state at high temperature ${ }^{\square}$. In the same range, the characteristic peaks of the particles prepared at $800^{\circ} \mathrm{C}$ corresponded to $\mathrm{Ca}_{2} \mathrm{SiO}_{4}, \mathrm{Na}_{2} \mathrm{Si}_{3} \mathrm{O}_{7}$ and $\mathrm{Ca}_{12} \mathrm{Al}_{14} \mathrm{O}_{33}$. This result indicated that the pre-product was a silicate gel containing $\mathrm{Ca}$ and $\mathrm{Na}$, the crystallinity increased between $600^{\circ} \mathrm{C}$ and $700^{\circ} \mathrm{C}$, and the crystalline phase was formed at $800^{\circ} \mathrm{C}$. Therefore, the crystallization of silicate gel decreases the binding force between bentonite and carbide slag and increases the loss rate of particles. Regarding the particles prepared at $600^{\circ} \mathrm{C}$, the characteristic peaks of $\mathrm{Ca}(\mathrm{OH})_{2}$ at $17.82^{\circ}$ and $33.97^{\circ}$ became flat and wide, and the characteristic peaks of $\mathrm{CaO}$ were found, which was due to the dehydration of $\mathrm{Ca}(\mathrm{OH})_{2}$ to $\mathrm{CaO}$. This finding was consistent with previous conclusions ${ }^{[]}$.

Figure 9 shows the SEM images of the surface morphologies of particles prepared at different temperatures. As Fig. 9a shows, the surface morphologies of the uncalcined particles are rough, and the layered structure is clearly visible. Due to the evaporation of free water inside the particles calcined at $200^{\circ} \mathrm{C}$, small cracks appeared, and the layered structure became blurred (Fig. 9b). This is consistent with the XRD results. Regarding the particles calcined at $500^{\circ} \mathrm{C}$, the surface morphologies became smooth, and the layered structure disappeared. The condensation of hydration products clarified the edge of the crack. Notably, this structure can more closely combine bentonite and carbide slag ${ }^{\square}$. Since $\mathrm{Ca}(\mathrm{OH})_{2}$ in the particles calcined at $600^{\circ} \mathrm{C}$ was dehydrated and converted to $\mathrm{CaO}$, the surface morphologies became more smooth (Fig. 9d). However, when the calcination temperature was increased to $800^{\circ} \mathrm{C}$ (Fig. 9e), many irregularly distributed silicate crystals appeared on the complex surface morphologies of the particles. The crystals filled the original pores and blurred the edges of the surface cracks. A rough surface is not conducive to resisting the flow shear force and friction between particles, which is one of the reasons for the increase in the loss rate. However, the increase in crystallization is not conducive to the removal of $\mathrm{Cu}^{2+}$ and leads to a continuous decrease in the $\mathrm{Cu}^{2+}$ removal rate.

\subsection{Alkali sustained-release property analysis}

Based on the above experiments, when the mass ratio of bentonite to carbide slag was 3:7, the dose of $\mathrm{Na}_{2} \mathrm{CO}_{3}$ was $10 \%$ of the total mass, and the particles were calcined at $500^{\circ} \mathrm{C}$ for $1 \mathrm{~h}$. The prepared particles had the best mechanical strength and $\mathrm{Cu}^{2+}$ removal rate. The sustained release properties of the alkali particles were analysed. Figure 10 shows the time it took to achieve a pH balance for $200 \mathrm{mg}$ of particles (containing $126 \mathrm{mg}$ of carbide slag) and $126 \mathrm{mg}$ of carbide slag powder in initial solutions at $\mathrm{pH}$ 3. The time for the release of basicity from the optimal particles to reach equilibrium was 180 min, four times that for carbide slag powder (45 min). Therefore, the composite particles demonstrated a good slow-release effect of basicity in water. 
The (001), (101) and (110) crystal planes of $\mathrm{Ca}(\mathrm{OH})_{2}$ in the raw carbide slag powder, uncalcined particles, and calcined particles at $200^{\circ} \mathrm{C}$ and $500^{\circ} \mathrm{C}$ were fitted by XRD, and the grain size was calculated by the Toylor formula. The effect of calcination temperature on the grain size of $\mathrm{Ca}(\mathrm{OH})_{2}$ was compared and analysed. The fitting results are shown in Table 2.

Table 2

Fitting results for the grain size of $\mathrm{Ca}(\mathrm{OH})_{2}$.

\begin{tabular}{|llllllll|}
\hline \multirow{2}{*}{ Crystal planes } & $\mathbf{( 0 0 1 )}$ & & $\mathbf{( 1 0 1 )}$ & & $\mathbf{( 1 1 0 )}$ & \multirow{2}{*}{ Fit Size (nm) } \\
\cline { 2 - 7 } & FWHM & XS(nm) & FWHM & XS(nm) & FWHM & XS(nm) & \\
\hline carbide slag & 0.309 & 275 & 0.347 & 250 & 0.298 & 313 & 267 \\
\hline $25^{\circ} \mathrm{C}$ & 0.303 & 281 & 0.340 & 256 & 0.325 & 284 & 268 \\
\hline $200^{\circ} \mathrm{C}$ & 0.321 & 363 & 0.370 & 233 & 0.320 & 289 & 249 \\
\hline $500^{\circ} \mathrm{C}$ & 0.361 & 232 & 0.439 & 194 & 0.389 & 234 & 211 \\
\hline
\end{tabular}

Table 2 shows that the grain size of $\mathrm{Ca}(\mathrm{OH})_{2}$ in the carbide slag powder is $267 \mathrm{~nm}$. After mixing with bentonite and $\mathrm{Na}_{2} \mathrm{CO}_{3}$ in the optimal proportion, the grain size of $\mathrm{Ca}(\mathrm{OH})_{2}$ in the particles without calcination was $268 \mathrm{~nm}$, and the grain size exhibited little change. After calcination, the grain size of $\mathrm{Ca}(\mathrm{OH})_{2}$ decreased from $268 \mathrm{~nm}$ to $211 \mathrm{~nm}$. This indicates that calcination effectively reduces the grain size of $\mathrm{Ca}(\mathrm{OH})_{2}$. This decrease in grain size can make the amorphous gel better encapsulate carbide slag, thus buffering the alkalinity release of the particles.

\section{Conclusion}

This study is the first attempt to use carbide slag, bentonite and a small amount of $\mathrm{Na}_{2} \mathrm{CO}_{3}$ to prepare alkalinity sustained-release particles, namely, carbide slag composite alkalinity sustained-release particles. The results showed that the adhesion of particles came from the adhesion of bentonite itself and the formation of hydrated silicate gel. $\mathrm{Na}_{2} \mathrm{CO}_{3}$ enhanced the activity of montmorillonite and silica in bentonite and played a significant role in promoting the formation of the gel phase. The gel formed between the interface of the carbide slag and bentonite made the two bonds. At room temperature, $\mathrm{SiO}_{2}$ is preferentially involved in the formation of gels. As the temperature increases, the reactivity of $\mathrm{Si}$ and $\mathrm{Al}$ in the montmorillonite structure increases to form hydrated silicate in amorphous. Furthermore, the gel lost water and shrunk at high temperature, condensing the particle structure and obtaining good mechanical strength. But at $\mathrm{T}>600^{\circ} \mathrm{C}$, the gel gradually transforms to the crystalline state, and the particle loss rate increases. The optimum preparation conditions of the composite alkalinity sustainedrelease particles were as follows: the mass ratio of bentonite and carbide slag of 3:7, the $\mathrm{Na}_{2} \mathrm{CO}_{3}$ dose of $10 \%$ of the total mass, and the calcination temperature of $500^{\circ} \mathrm{C}$ for $1 \mathrm{~h}$. The fitting results of the grain size showed that the grain size of $\mathrm{Ca}(\mathrm{OH})_{2}$ decreased from $268 \mathrm{~nm}$ to $211 \mathrm{~nm}$, which made the hydrated silicate gel better encapsulate the $\mathrm{Ca}(\mathrm{OH})_{2}$ and reduced the basicity release rate of the carbide slag by 4 
times. Therefore, carbide slag composite alkalinity sustained-release particles can replace limestone as a new filling material in the ALDs which is beneficial for preventing the formation of AMD from the source.

\section{Declarations}

\section{Data Availability}

All data generated or analysed during this study are included in this published article.

\section{Acknowledgments}

This project was funded by the National Natural Science Foundation of China $(51474122,51174267)$ and Millions of Talents Project of Liaoning Province (2014921069).

\section{Author contributions}

J. B.: Conceptualization, Formal analysis, Investigation, Methodology, Validation, Writing - original draft, Writing - review \& editing. H. Z.: Conceptualization, Methodology, Funding acquisition, Project administration, Writing - review \& editing. L. X.: Conceptualization, Funding acquisition, Methodology. All authors have read and agreed to the published version of the manuscript.

\section{Author information}

Affiliations

School of Environmental Science and Engineer, Liaoning Technical University, Fuxin,123000

Jichi Bai, Haiqin Zhang \& Liping Xiao

School of Environmental and Municipal Engineering, Qingdao University of Technology,

Liping Xiao

Competing interests

The authors declare no competing interests.

\section{References}

1. Das, A., Kumar, R., Patel, S. S., Saha, M. C. \& Guha, D. Source apportionment of potentially toxic elements in street dust of a coal mining area in Chhattisgarh, India, using multivariate and lead isotopic ratio analysis. Environ. Monit. Assess. 192, 396 (2020). 
2. Punia, A. Role of temperature, wind, and precipitation in heavy metal contamination at copper mines: a review. Environ. Sci. Pollut. Res. 28, 4056-4072 (2021).

3. Bhuiyan, M. A. H., Parvez, L., Islam, M. A., Dampare, S. B. \& Suzuki, S. Heavy metal pollution of coal mine-affected agricultural soils in the northern part of Bangladesh. J. Hazard. Mater. 173, 384-392 (2010).

4. Rehman, I. U. et al. Enrichment, spatial distribution of potential ecological and human health risk assessment via toxic metals in soil and surface water ingestion in the vicinity of Sewakht mines, district Chitral, Northern Pakistan. Ecotoxicol. Environ. Saf. 154, 127-136 (2018).

5. Nieto, J. M. et al. Acid mine drainage pollution in the Tinto and Odiel rivers (Iberian Pyrite Belt, SW Spain) and bioavailability of the transported metals to the Huelva Estuary. Environ. Int. 33, 445-455 (2007).

6. Aguiar, A. O. et al. Gold acid mine drainage treatment by membrane separation processes: An evaluation of the main operational conditions. Sep. Purif. Technol. 170, 360-369 (2016).

7. Qureshi, A., Maurice, C. \& Öhlander, B. Potential of coal mine waste rock for generating acid mine drainage. J. Geochem. Explor. 160, 44-54 (2016).

8. Sheibach, R. B., Williams R. E., \& Genes B. R. Controlling acid mine drainage from the Ficher Mining District, Oklahoma, United States. Int. J. Mine Water. 1, 45-52 (1982).

9. Casiot, C. et al. Geochemical Processes Controlling the Formation of As-Rich Waters Within a Tailings Impoundment (Carnoulès, France). Aquat. Geochem. 9, 273-290 (2003).

10. Kefeni, K. K., Msagati, T. A. M. \& Mamba, B. B. Acid mine drainage: Prevention, treatment options, and resource recovery: A review. J. Clean. Prod. 151, 475-493 (2017).

11. Loos, M. A., Bosch, C., Mare『, J., Immelman, E. \& Sanderson, R. D. Evaluation of sodiumlauryl sulfate, sodium benzoate and sorbic acid as inhibitors of acidification of South African coal waste. Groundwater and Mining: Proceedings of the 5th Biennial Symposium of the Groundwater Division of the Geological Survey of South Africa Randberg, Transvaal. Pretoria7 Geological Society of South Africa. 193-200 (1989).

12. Ziemkiewicz, P. F., Skousen, J. G. \& Lovett, R. Open limestone channels for treating acid mine drainage: a new look at an old idea. Green Lands. 24, 36-41 (1994).

13. Ziemkiewicz, P. F., Skousen, J. G., Brant, D. L., Sterner, P. L. \& Lovett, R. J. Acid mine drainage treatment with armored limestone in open limestone channels. Environ. Qual. 26, 718-726 (1997).

14. Cravotta, C. A. Size and performance of anoxic limestone drains to neutralize acidic mine drainage. J. Environ. Qual. 32, 1277-1289 (2003).

15. Yanful, E. K., Shikatani, K. S. \& Quirt, D. H. Hydraulic conductivity of natural soils permeated with acid mine drainage. Can. Geotech. J. 32, 624-646 (1996).

16. Shackelford, C. D., Sevick, G. W. \& Eykholt, G. R. Hydraulic conductivity of geosynthetic clay liners to tailings impoundment solutions. Geotext. Geomembranes, 28, 149-162 (2010). 
17. Skousen, J. et al. Review of Passive Systems for Acid Mine Drainage Treatment. Mine Water Environ. 36, 133-153 (2016).

18. Ziemkiewicz, P. F., Skousen, J. G. \& Simmons, J. Long-term Performance of Passive Acid Mine Drainage Treatment Systems. Mine Water Environ. 22, 118-129 (2003).

19. Turner, D. \& McCoy D. Anoxic alkaline drain treatment system, a low cost acid mine drainage treatment alternative. P.73-75. In D.H. Graves (ed.) Proc. of the National Symp. on Mining, Lexington, $\mathrm{KY}$. Univ. of Kentucky, Lexington, KY.

20. Johnson, D. B. \& Hallberg, K. B., Acid mine drainage remediation options: a review. Sci. Total Environ. 338, 3-14 (2005).

21. Barton, P. \& Vatanatham, T. Kinetics of limestone neutralization of acid waters. Environ. Sci. Technol. 10, 262-266 (1976).

22. Evangelou, V. P. Pyrite Chemistry: The Key for Abatement of Acid Mine Drainage. Acidic Mining Lakes, 197-222 (1998).

23. Feng, D., Deventer, J. \& Aldrich, C. Removal of pollutants from acid mine wastewater using metallurgical by-product slags. Sep. Purif. Technol. 40, 61-67 (2004).

24. Potgieter-Vermaak, S. S., Potgieter, J. H., Monama, P. \& Grieken, R. V. Comparison of limestone, dolomite and fly ash as pre-treatment agents for acid mine drainage. Miner. Eng. 19, 454-462 (2006).

25. Bernier, $L$. The potential use of serpentinite in the passive treatment of acid mine drainage: batch experiments. Environ. Geol. 47, 670-684 (2005).

26. Kamal, N. M. \& Sulaiman, S. K. Bench-scale study of acid mine drainage treatment using local neutralisation agents. Malaysian Journal of Fundamental and Applied Sciences. 10, 150-153 (2014).

27. Petrik, L. F. et al. Utilization of South African Fly Ash to Treat Acid Coal Mine Drainage, and Production of High Quality Zeolites from the Residual Solids. 2003 International Ash Utilization Symposium, Center for Applied Energy Research, University of Kentucky, Paper \#61 (2003).

28. Turigan, C. et al. A comparison of the acid mine drainage (AMD) neutralization potential of low grade nickel laterite and other alkaline-generating materials. 2020 IOP Conf. Ser.: Mater. Sci. Eng. 778, 012142 (2020).

29. Hariani, P. L., Salni, S. \& Riyanti, F. Combination of $\mathrm{CaCO} 3$ and $\mathrm{Ca}(\mathrm{OH}) 2$ as agents for treatment acid mine drainage. Matec. Web of Conferences. 101, 02004 (2017).

30. Fang, D. et al. Evaluation of porous calcium silicate hydrate derived from carbide slag for removing phosphate from wastewater. Chem. Eng. J. 354, 1-11 (2018).

31. Sun, Y., Ma, J., Chen, Y., Tan, B. \& Cheng, W. Mechanical behavior of copper-contaminated soil solidified/stabilized with carbide slag and metakaolin. Environ. Earth Sci. 79, 423 (2020).

32. Provis, J. L. \& Deventer, J. S. J. V. Alkali Activated Materials. RILEM State Art Report. 13, 59-91 (2014).

33. Provis, J. L., Myers, R. J.; White, C. E., Rose. V. \& Deventer, J. S. J. V. X-ray microtomography shows pore structure and tortuosity in alkali-activated binders. Cement Concrete Res. 42, 855-864 (2012). 
34. Monteiro, A. et al. Efficient immobilization of montmorillonite onto cotton textiles through their functionalization with organosilanes. Appl. Clay Sci. 101, 304-314 (2014).

35. Luckham, P. F. \& Rossi, S. The colloidal and rheological properties of bentonite suspensions. $A d v$. Colloid Interfac. 82, 43-92 (1999).

36. Mo, W. et al. Preparation and characterization of a granular bentonite composite adsorbent and its application for $\mathrm{Pb}^{2+}$ adsorption. Appl. Clay Sci. 159, 68-73 (2018).

37. Provis, J. L. Alkali-activated materials. Cement Concrete Res. 114, $40-48$ (2017).

38. Wang, L. et al. Green remediation of As and $\mathrm{Pb}$ contaminated soil using cement-free clay-based stabilization/solidification. Environ. Int. 126, 336-345 (2019).

39. Zhang, P. et al. Self-cementation solidification of heavy metals in lead-zinc smelting slag through alkali-activated materials. Constr. Build. Mater. 249, 118756 (2020).

40. Kiventer, J., Perumal, P., Yliniemi, J. \& Illikainen, M. Mine tailings as a raw material in alkali activation: A review. Int. J. Miner. Metall. Mater. 27, 1009-1020 (2020).

41. Zhan, X., Xiao, L. \& Liang, B. Experimental Study on the Optimum Preparation of Bentonite-Steel Slag Composite Particles. Sustainability. 12, 18 (2020).

42. Al-Hammod, A. A., Frayyeh, Q. J. \& Abbas, W. A. Thermally Activated Bentonite As a Supplementary Cementitious Material - A Review. Eng. Technol. J. 39, 206-213 (2021).

43. Okano, K. et al. Novel technique for phosphorus recovery from aqueous solutions using amorphous calcium silicate hydrates (A-CSHs). Water Res. 47, 2251-2259 (2013).

44. Gameiro, A. L., Silva, A. S., Veiga, M. D. R. \& Velosa, A. L. Lime-metakaolin hydration products: a microscopy analysis. Mater. Tehnol. 46, 145-148 (2012).

45. Marsh, A., Heath, A., Patureau, P., Mark, E. \& Pete, W. Alkali activation behaviour of un-calcined montmorillonite and illite clay minerals. Appl. Clay Sci. 166, 250-261 (2018).

46. Niu S., Liu, M., Lu, C., Li, H. \& Huo, M. Thermogravimetric analysis of carbide slag. J. Therm. Anal. Calorim. 115, 73-79 (2014).

47. Zhang, J. et al. Preparation of CaO-containing carbon pellet from recycling of carbide slag: Effects of temperature and $\mathrm{H} 3 \mathrm{PO} 4$. Waste Manage. 84, 64-73.

48. Bojemueller, E., Nennemann, A. \& Lagaly, G. Enhanced pesticide adsorption by thermally modified bentonites. Appl. Clay Sci. 18, 277-284 (2001).

\section{Figures}




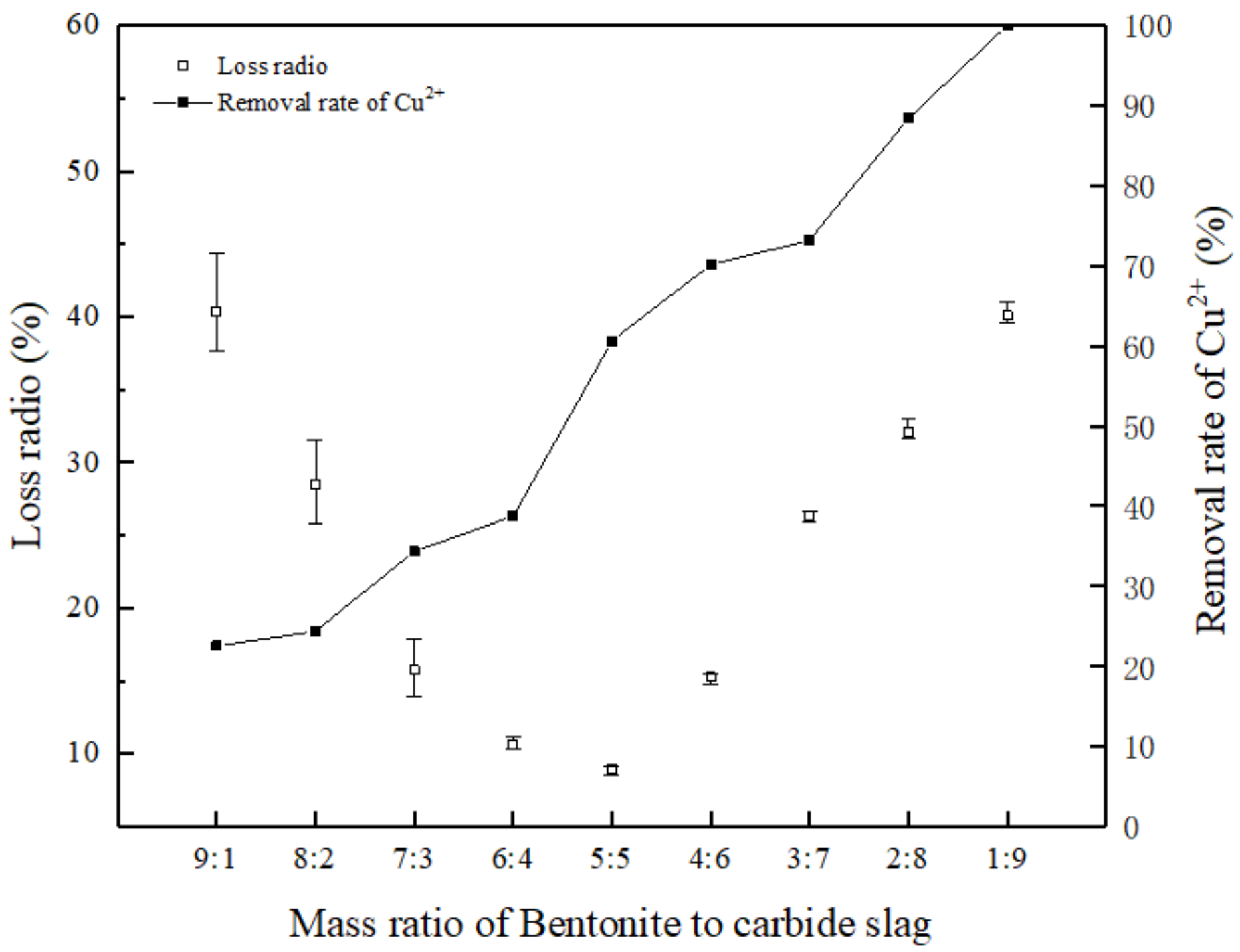

Figure 1

Effect of different proportions on particle loss rate and Cu2+ removal rate. 

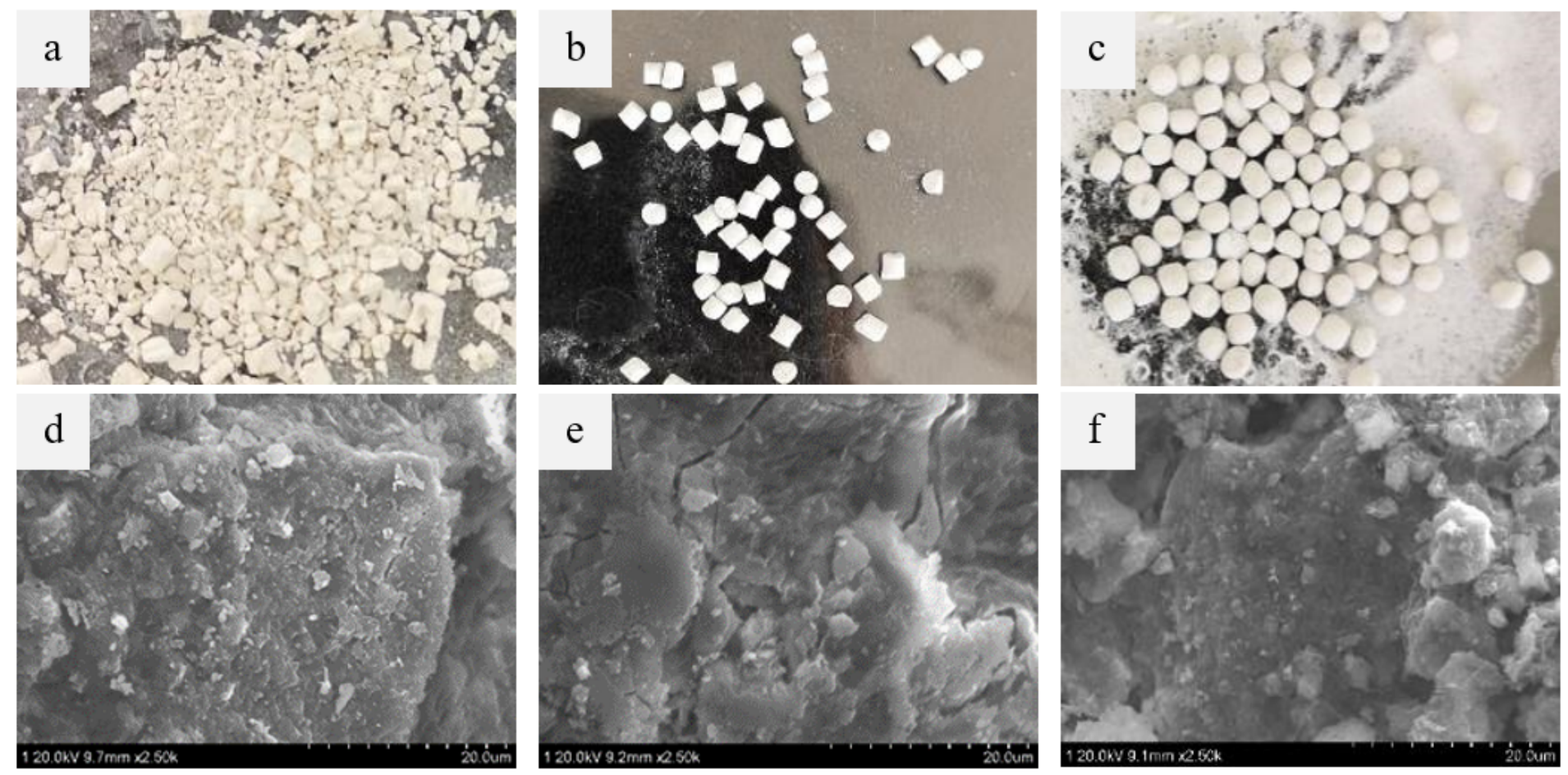

Figure 2

Loss of typical particles in water and the SEM images: (a), (d) 9:1 particles, (b), (e) 5:5 particles, and (c), (f) 1:9 particles.
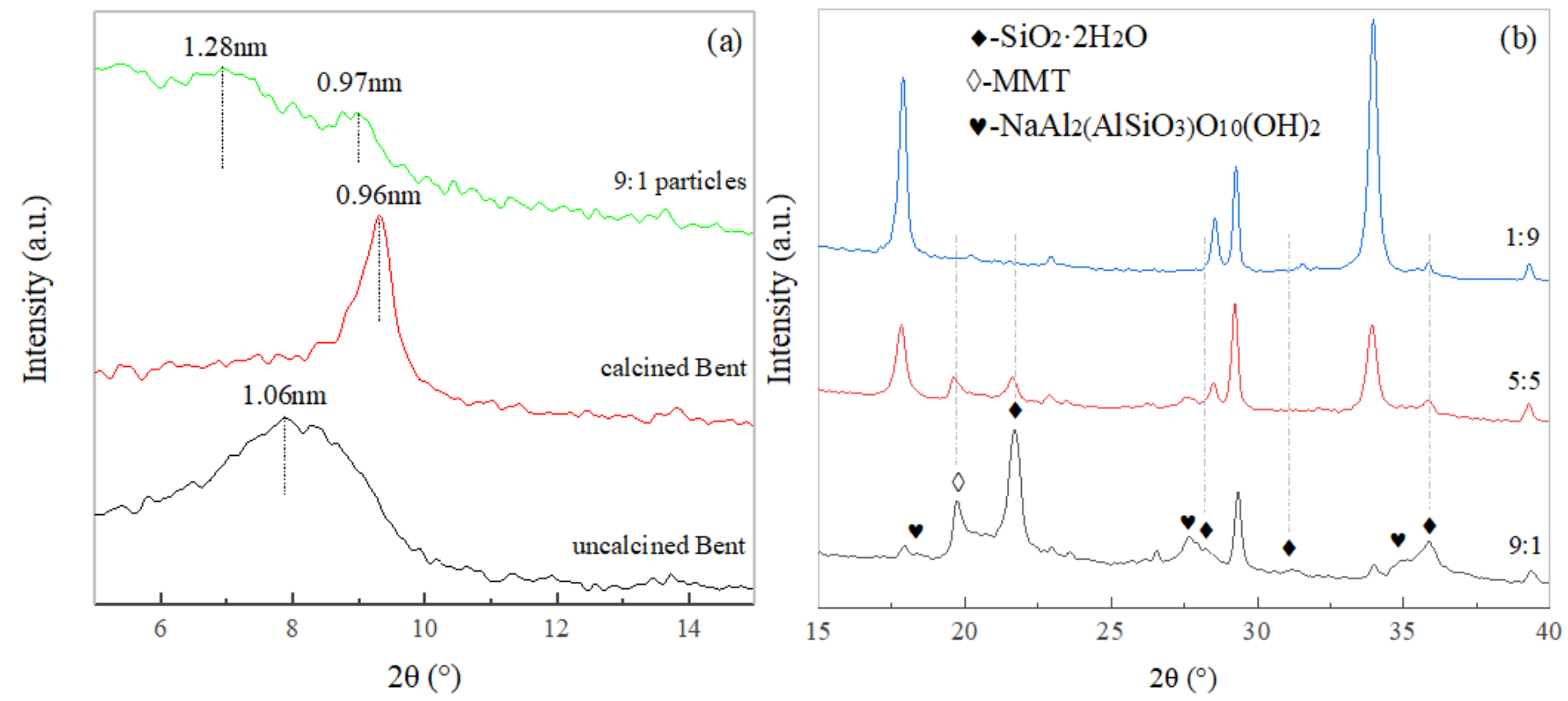

Figure 3

XRD diffraction data: (a) uncalcined bentonite, calcined bentonite $\left(500{ }^{\circ} \mathrm{C}\right)$ and 9:1 particles and (b) 9:1 particles, 5:5 particles and 1:9 particles. 

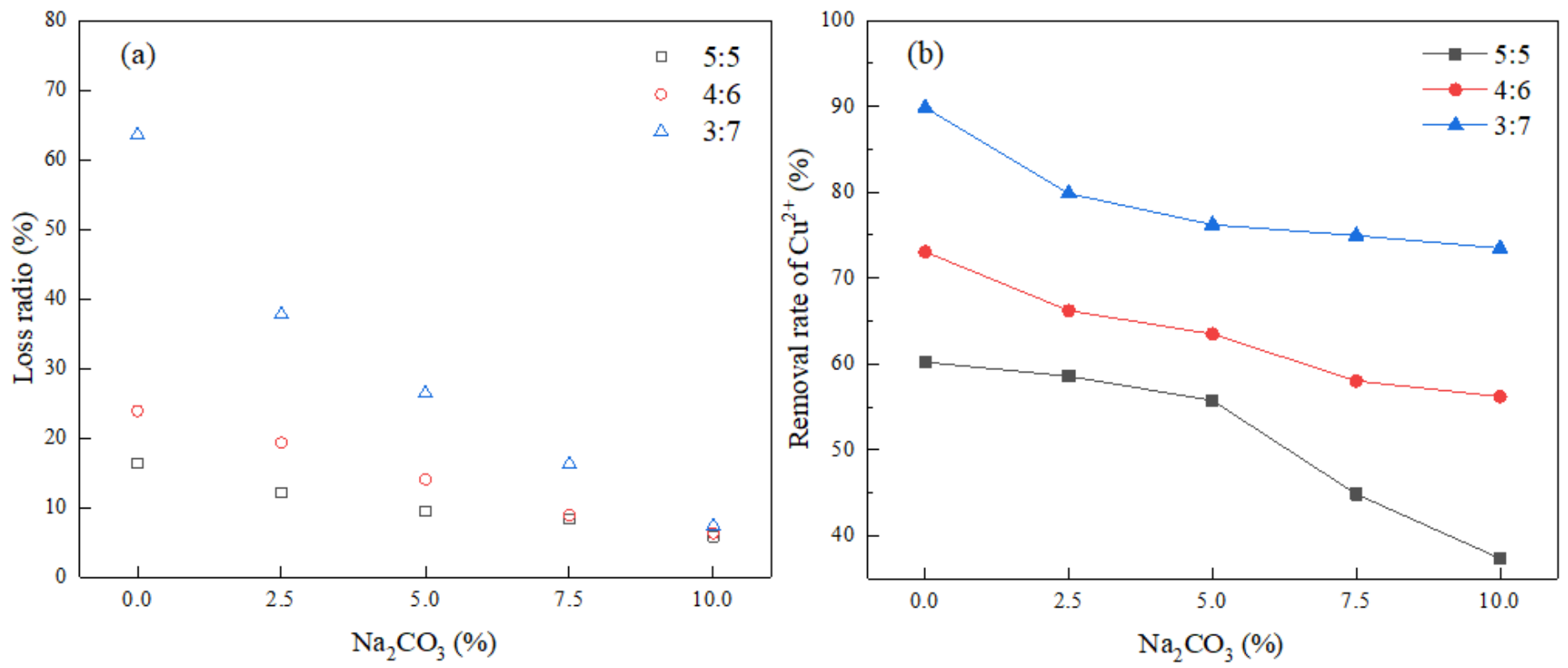

Figure 4

Effect of different $\mathrm{Na} 2 \mathrm{CO} 3$ doses on the (a) particle loss rate and (b) Cu2+ removal rate.
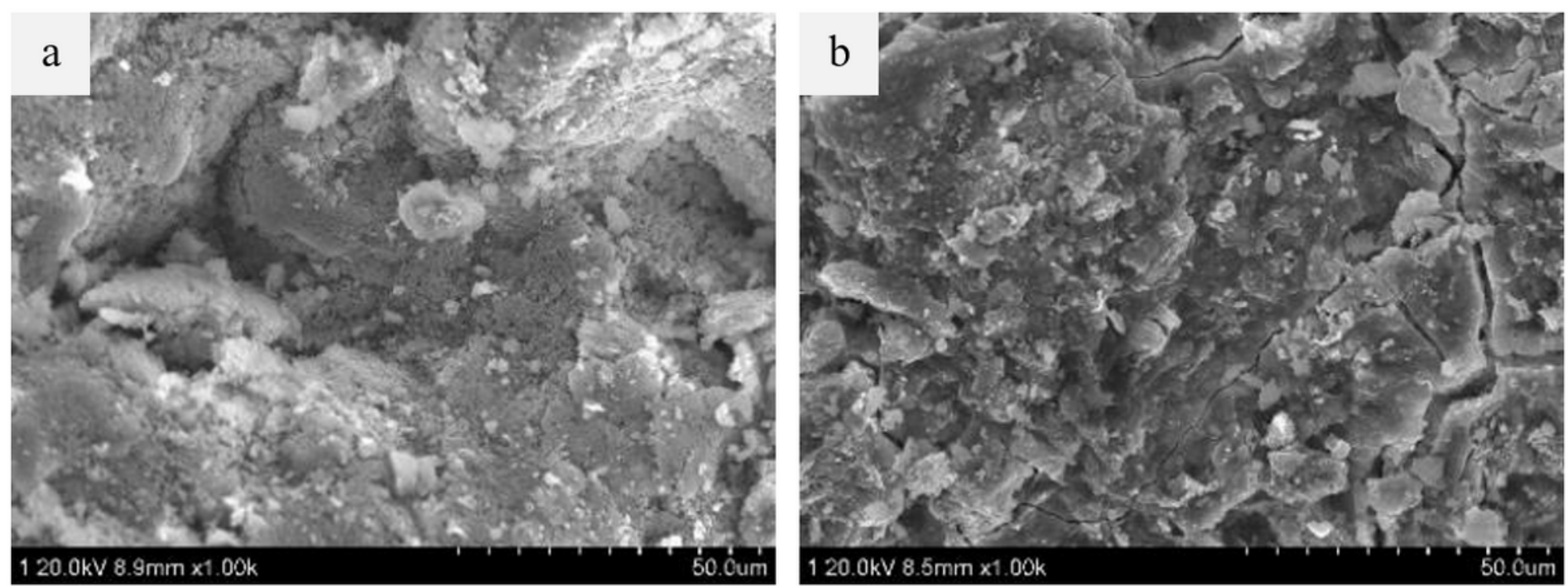

Figure 5

SEM images of the 7:3 particles with (a) $0 \%$ and (b) $10 \% \mathrm{Na} 2 \mathrm{CO} 3$. 


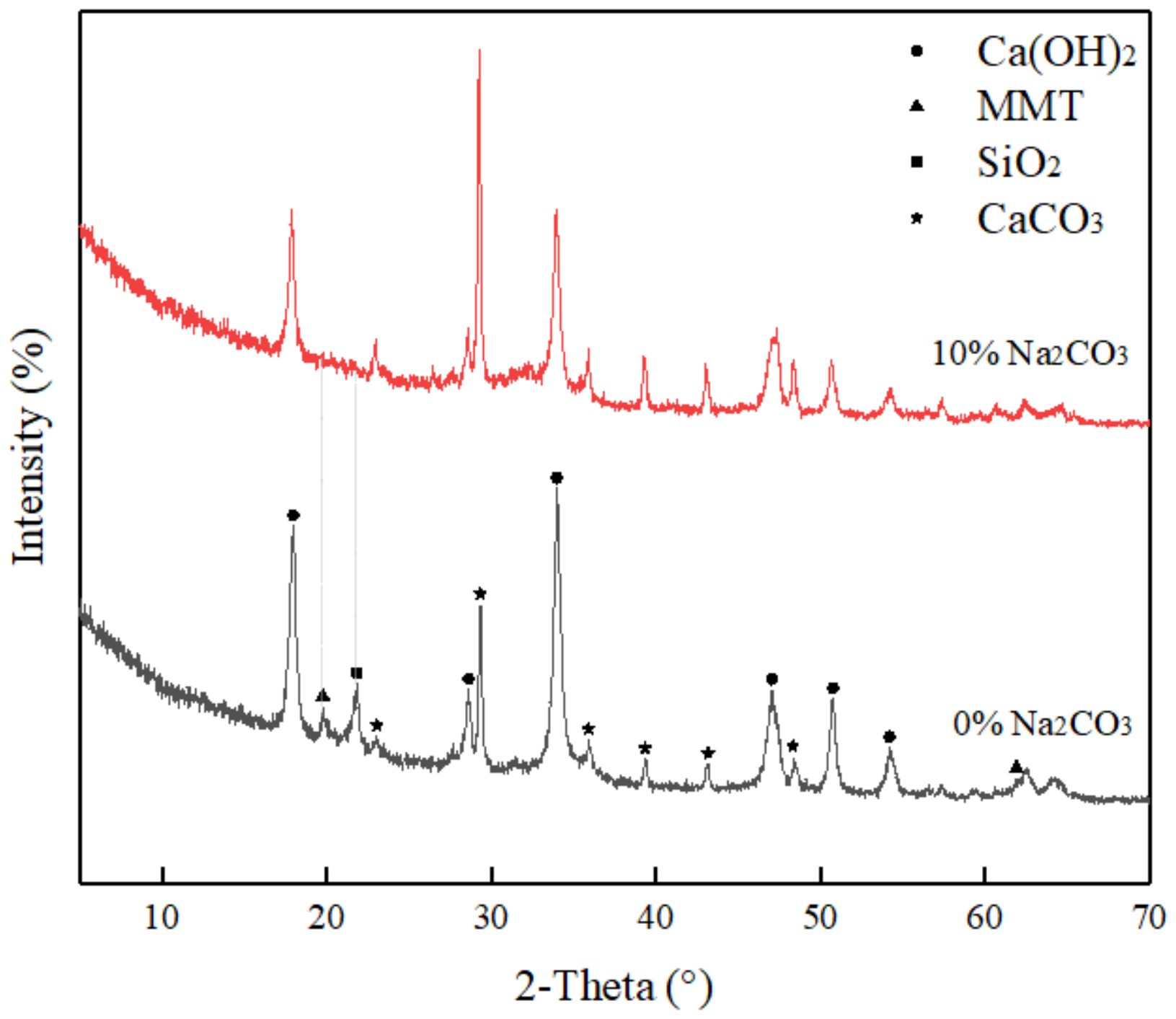

Figure 6

XRD patterns of the particles without $\mathrm{Na} 2 \mathrm{CO} 3$ and with $10 \% \mathrm{Na} 2 \mathrm{CO}$. 


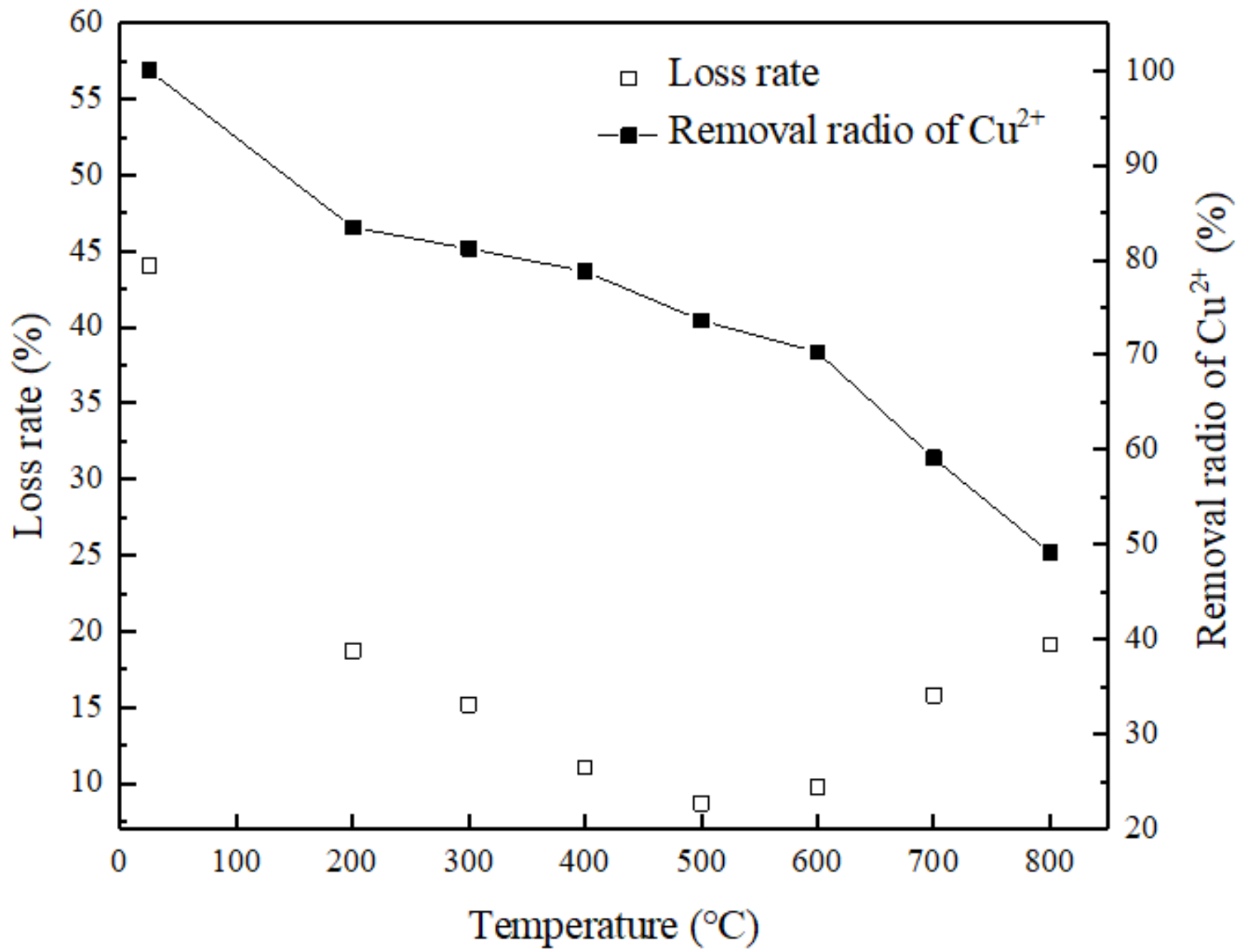

Figure 7

Effect of the different calcination temperatures on the particle loss rate and Cu2+ removal rate. 


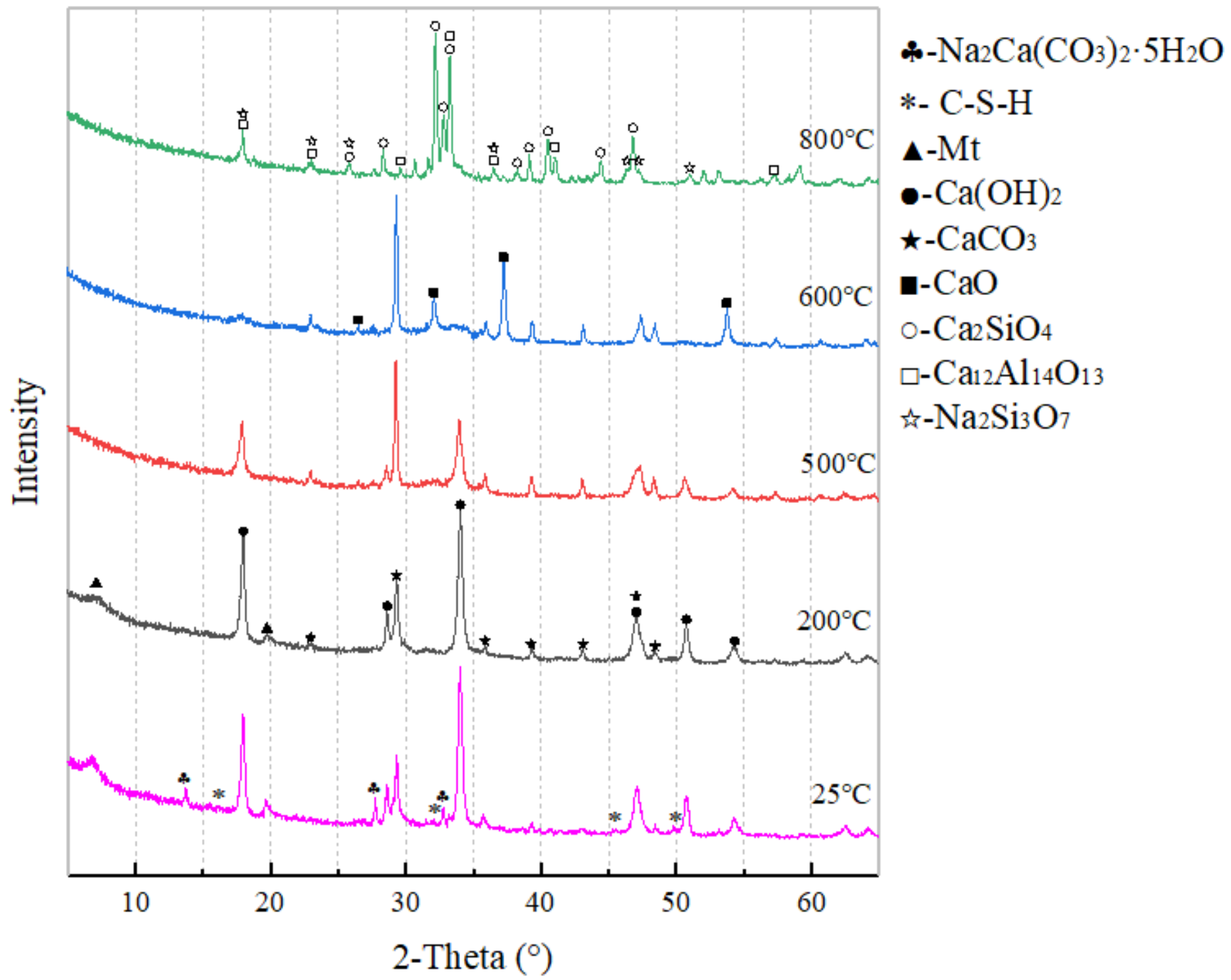

Figure 8

XRD patterns of the composite particles at different temperatures. 

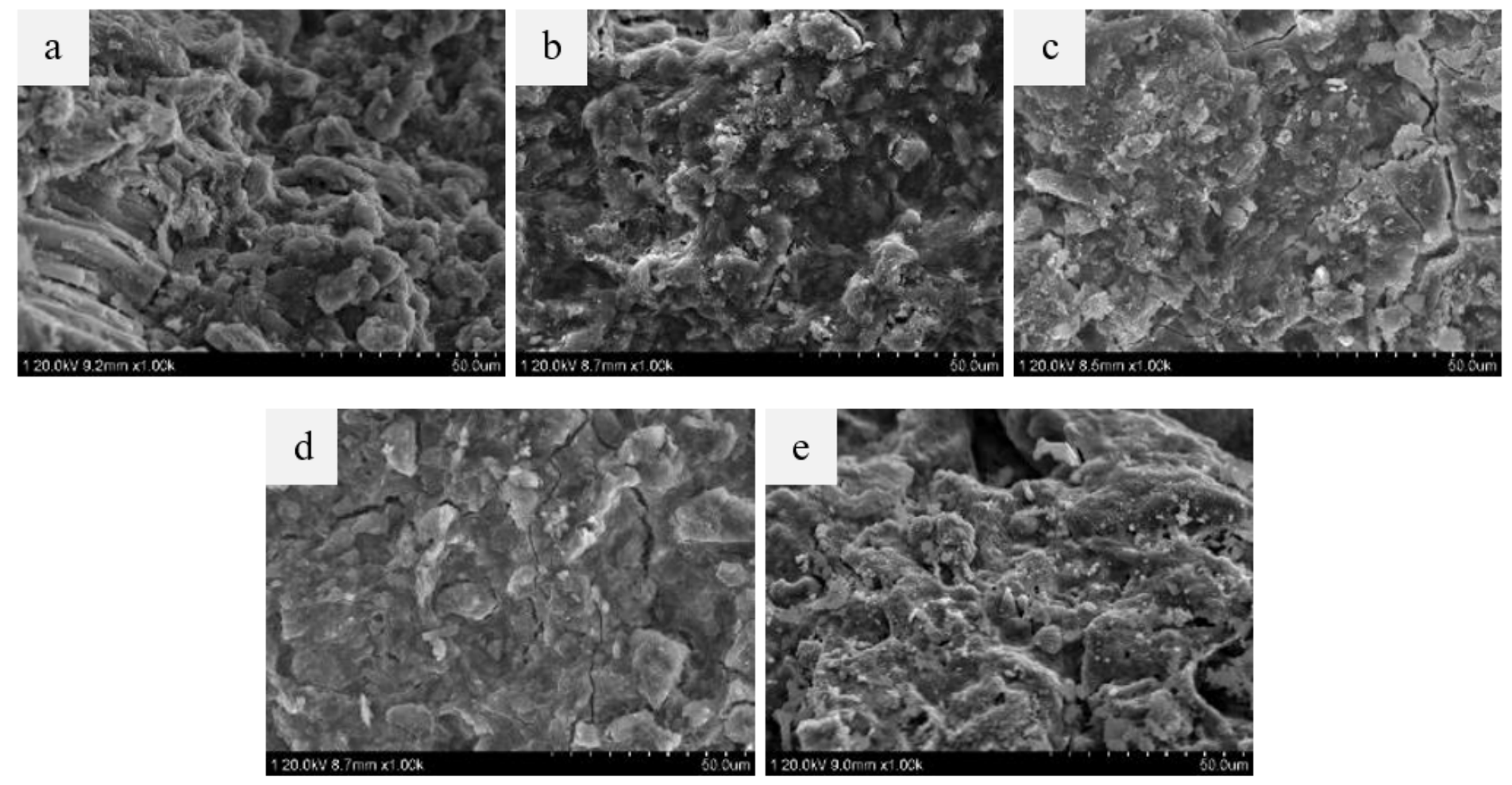

Figure 9

SEM images of the composite particles at different calcination temperatures: (a) $25^{\circ} \mathrm{C}$, (b) $200{ }^{\circ} \mathrm{C}$, (c) 500 ${ }^{\circ} \mathrm{C}$, (d) $600{ }^{\circ} \mathrm{C}$, and (e) $800{ }^{\circ} \mathrm{C}$. 


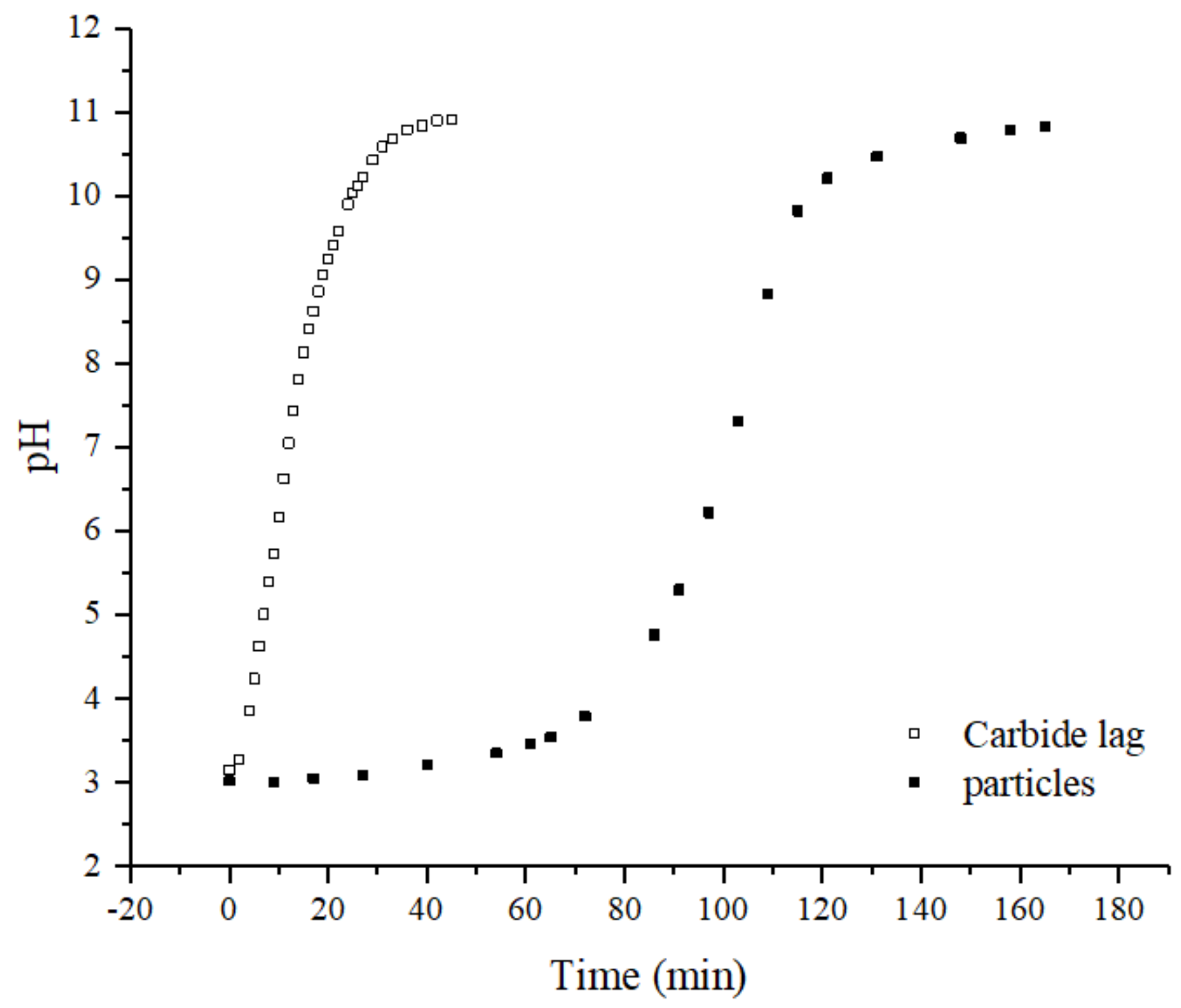

Figure 10

Comparison of the basicity release rates of the optimal composite particles and carbide slag powder. 